\title{
DECOMPOSITION AND NUTRIENT DYNAMICS IN A Spartina alterniflora MARSH OF THE BAHIA BLANCA ESTUARY, ARGENTINA
}

\author{
Vanesa L. Negrin ${ }^{1, *}$, Gabriela González Trilla ${ }^{2}$, Patricia Kandus ${ }^{2}$ and Jorge E. Marcovecchio ${ }^{\text {I, } 3}$ \\ ${ }^{1}$ Instituto Argentino de Oceanografía - CONICET \\ (CC 804, Camino La Carrindanga km 7.5, CCT-CONICET-BB, Edificio E1, (8000) Bahía Blanca, Argentina) \\ ${ }^{2}$ Universidad de San Martín - Laboratorio de Ecología, Teledetección y Eco-Informática, Instituto de \\ Investigaciones e Ingeniería Ambiental (3iA) \\ (Peatonal Belgrano 3563, piso1, (1650) San Martín, Argentina)
}

${ }^{3}$ Universidad de la Fraternidad de Agrupaciones Santo Tomás de Aquino (FASTA), (Gascón 3145, (7600) Mar del Plata, Argentina)

*Corresponding author: vlnegrin@ criba.edu.ar

Descriptors: Spartina alterniflora, Decomposition, Nutrients, Argentinian salt marsh.

Descritores: Spartina alterniflora, Descomposição, Nutrientes, Marisma Argentina.

Salt marshes are among the most productive systems in the world. As a consequence, they also produce great amounts of litter (e.g. BOUCHARD; LEFEUVRE, 2000; MONTEMAYOR et al., 2011), which becomes a large and renewable pool of organic matter and nutrients. Litter alternately releases and absorbs nutrients (especially of $\mathrm{C}, \mathrm{N}$ and $\mathrm{P}$ ) as it decomposes (JORDAN et al., 1989). Hence, detritus is a considerable energy source for microorganisms in the marsh and the adjacent estuary, being the basis of the food web in these ecosystems (MOORE et al., 2004). On the other hand, the concentration of $\mathrm{C}, \mathrm{N}$ and $\mathrm{P}$ in the tissues and, most importantly, the ratios between them, are factors that determine the rate of decomposition (ENRIQUEZ et al., 1993; REJMÁNKOVÁ; HOUDKOVÁ, 2006).

Spartina alterniflora Loisel (Poaceae) is a highly productive species and subjected daily to tidal flooding, so its trophic importance in the marshestuarine ecosystem has been deeply investigated (e.g. MARINUCCI, 1982; DAME, 1989; LIAO et al., 2007). However, published studies on the decomposition of this species are mainly related to salt marshes in the United States (e.g. FRASCO; GOOD, 1982; WILSON et al., 1986; BENNER et al., 1991). In South America, the ecological behavior of salt marshes is not well understood due not only to the sparse information available on S. alterniflora itself, especially regarding belowground tissues (DA CUNHA LANA et al., 1991; BIUDES; CAMARGO, 2006; GONZÁLEZ TRILLA et al., 2009; PELÁEZ et al., 2009; MONTEMAYOR et al., 2011), but also on the distribution of organic matter and nutrients in environments where it grows (NEGRIN et al., 2011). Thus, the aim of this study was to estimate aboveground and belowground decomposition rates in a $S$. alterniflora salt marsh located on the Bahía Blanca estuary (Argentina) and evaluate $\mathrm{C}, \mathrm{N}$ and $\mathrm{P}$ dynamics during this process.

The Bahía Blanca estuary, Argentina, a mesotidal system with a semidiurnal regime and extensive mudflats and salt marshes (PICCOLO et al., 2008), is located between $38^{\circ} 45$ and $39^{\circ} 25 \mathrm{~S}$ and $61^{\circ} 45$ and $62^{\circ} 25$ W. S. alterniflora, the second most important halophytic species of this estuary, covers approximately $100 \mathrm{~km}^{2}$ (ISACCH et al., 2006). The study site is a salt marsh located in the middle zone of the estuary, where $S$. alterniflora is the dominant species.

Decomposition of aboveground and belowground biomass was determined from the disappearance of material from litter bags (BOCOCK; GILBERT, 1957). The plant tissues, collected in the high marsh, were gently rinsed and then dried at $60^{\circ} \mathrm{C}$ for $72 \mathrm{~h}$. Approximately $20 \mathrm{~g}$ and $10 \mathrm{~g}$ of dry above (leaves and shoots) and belowground (roots and rhizomes) components, respectively, were placed in 20 x $20 \mathrm{~cm}$ plastic bags ( $2 \mathrm{~mm}$ mesh size). The bags were labeled and their contents individually weighed. Thirty-two bags with aerial tissues and twenty-one with belowground biomass were placed in the field in October 2006 and May 2007, respectively; the latter were buried at a depth of $10 \mathrm{~cm}$ and the former were laid on the sediment surface. At bimonthly intervals during a year, three or four bags were removed and taken to the laboratory. The content of each bag was washed, dried and weighed. Two bags of each sampling date were analyzed for the $\mathrm{C}, \mathrm{N}$ and $\mathrm{P}$ content (\%) using standardized methods (determinations made by LANAIS N-15, CONICETUNS). The initial content was also analyzed. 
After a year, $52.69 \pm 3.59 \%$ of the initial aboveground biomass remained in the field, meaning that the annual decomposition rate was $47.3 \pm 3.6 \%$; the process showed an exponential decrease $\left(\mathrm{R}^{2}=0.90\right)$ (Fig. 1a). The decomposition rate was slow in the first 120 days, with a percentage of daily loss of $0.025 \%$. Then, between the 60th and 120th day, the daily loss rate increased to $0.3 \%$, the greatest loss of biomass $(19.34 \pm 6.31 \%)$ taking place in this period. In the following periods, decomposition declined slightly regarding the previous period (Fig. 1a). For belowground tissues, $71.23 \pm 1.91 \%$ of the initial biomass remained in the field, meaning that the annual decomposition rate was $28.8 \pm 1.9 \%$; the process showed a general trend to an exponential decrease $\left(\mathrm{R}^{2}=0.66\right)$ (Fig. 1b). During the first 60 days there was a daily loss of mass of only $0.03 \%$. The greatest loss of biomass occurred between the 60th and 120th day, when $23.95 \pm 2.0-4 \%$ of the remaining biomass was lost $(0.38 \%$ daily $)$. Then, the remaining biomass stayed more or less constant until the end of the year (Fig. 1b).
In aboveground tissues, the content of $\mathrm{C}, \mathrm{N}$ and $\mathrm{P}$ was, on average, of $41.45 \pm 0.41 \%, 0.73 \pm 0.01$ $\%$ and $0.049 \pm 0.008 \%$, respectively, with fluctuations over the study period (Table 1). At the end of the period, the $\mathrm{C}$ concentration increased slightly in relation to the initial one $(102 \%)$ while the $\mathrm{N}$ and $\mathrm{P}$ concentrations decreased ( 95 and $72 \%$, respectively). The ratios between the elements analyzed also varied during the period, always being higher than 50 , 500 and 9 for $\mathrm{C} / \mathrm{N}, \mathrm{C} / \mathrm{P}$ and N/P, respectively (Table 1). For belowground tissues, the $\mathrm{C}, \mathrm{N}$ and $\mathrm{P}$ content was, on average, of $36.39 \pm 0.86 \%, 0.75 \pm 0.07 \%$ and $0.035 \pm 0.005 \%$, respectively, with fluctuations over the study period (Table 1). At the end of the period, the $\mathrm{C}$ and $\mathrm{P}$ concentrations increased slightly in relation to the initial ones (108 and $116 \%$, respectively) while the $\mathrm{N}$ concentration increased by more than twice $(216 \%$, respectively). The ratios between the elements analyzed were higher than those in the aboveground tissues and also varied over the period, always being higher than 38, 600 and 13 for $\mathrm{C} / \mathrm{N}, \mathrm{C} / \mathrm{P}$ and N/P, respectively (Table 1 ).
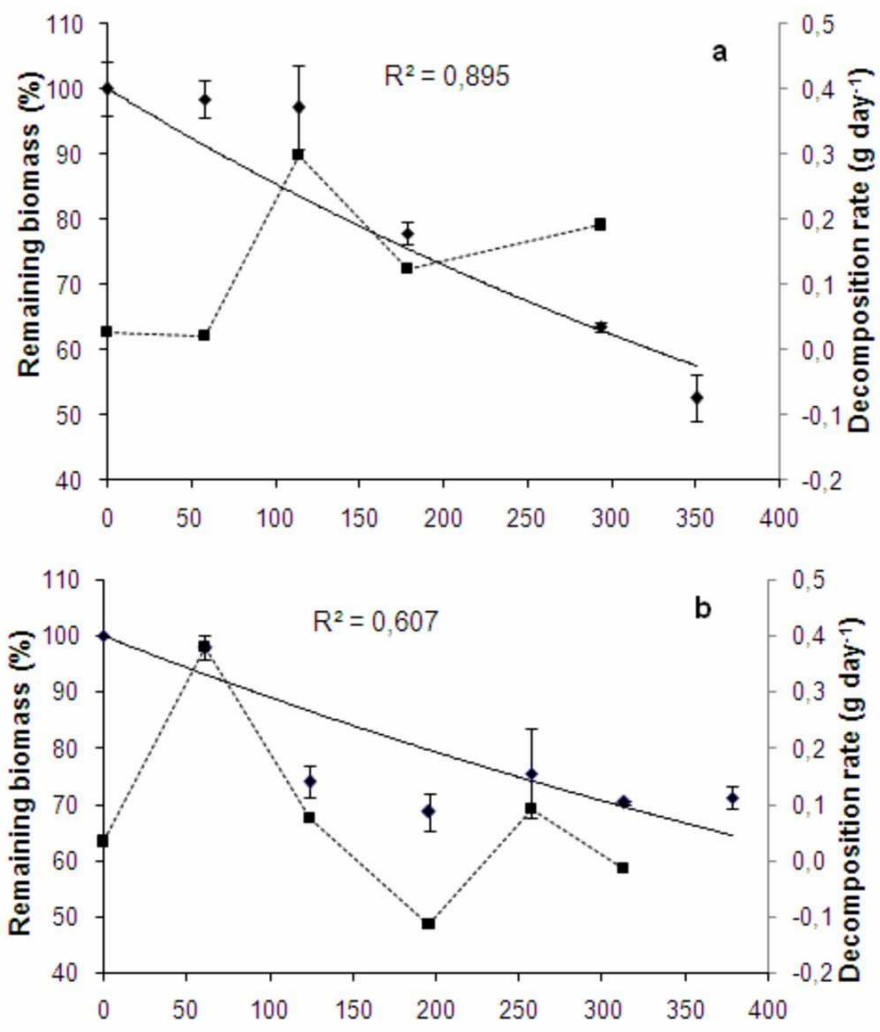

Fig.1. Remaining biomass present in the aboveground (a) and belowground (b) decomposition bags along the study period (black dots) (mean \pm SE) with a exponential approximation (solid line). Daily decomposition rates are also shown (dotted line). 
Table 1. Percentage of carbon $(\mathrm{C})$, nitrogen $(\mathrm{N})$ and phosphorus $(\mathrm{P})$ content and the ratios between them in above and belowground tissues along the study period (mean $\pm \mathrm{SE})$.

\begin{tabular}{lllllll}
\hline \hline Days & \multicolumn{1}{c}{$\mathbf{C}(\boldsymbol{\%})$} & $\mathbf{N}(\boldsymbol{\%})$ & \multicolumn{1}{c}{$\mathbf{P}(\boldsymbol{\%})$} & \multicolumn{1}{c}{$\mathbf{C} / \mathbf{N}$} & \multicolumn{1}{c}{$\mathbf{C} / \mathbf{P}$} & \multicolumn{1}{c}{$\mathbf{N} / \mathbf{P}$} \\
\hline & \multicolumn{5}{c}{ Aboveground tissues } \\
\hline $\mathbf{0}$ & 41.30 & 0.771 & 0.081 & 53.57 & 512.09 & 9.56 \\
$\mathbf{5 8}$ & $39.6 \pm 0.015$ & $0.68 \pm 0.09$ & $0.041 \pm 0.007$ & $59.09 \pm 7.94$ & $1008.78 \pm 173.90$ & $16.98 \pm 0.66$ \\
$\mathbf{1 1 4}$ & $41.34 \pm 0.93$ & $0.77 \pm 0.08$ & $0.046 \pm 0.0042$ & $54.68 \pm 7.31$ & $890.85 \pm 60.20$ & $16.73 \pm 3.34$ \\
$\mathbf{1 7 9}$ & $42.32 \pm 0.42$ & $0.73 \pm 0.03$ & $0.016 \pm 0.0006$ & $57.65 \pm 2.81$ & $2663.68 \pm 130.43$ & $46.20 \pm 0.009$ \\
$\mathbf{2 9 4}$ & $41.4 \pm 0.085$ & $0.67 \pm 0.01$ & $0.052 \pm 0.013$ & $61.26 \pm 0.87$ & $840.02 \pm 206.58$ & $13.66 \pm 3.17$ \\
$\mathbf{3 5 1}$ & $42.71 \pm 0.33$ & $0.73 \pm 0.01$ & $0.058 \pm 0.022$ & $58.47 \pm 1.89$ & $871.24 \pm 343.54$ & $14.72 \pm 5.40$ \\
\hline & & & $\mathbf{B e l o w g r o u n d}$ tissues & & \\
\hline $\mathbf{0}$ & $34.81 \pm 1.55$ & $0.47 \pm 0.062$ & $0.030 \pm 0.0049$ & $74.17 \pm 6.35$ & $1166.88 \pm 137.43$ & $15.69 \pm 0.51$ \\
$\mathbf{6 1}$ & $33.07 \pm 0.13$ & $0.87 \pm 0.11$ & $0.019 \pm 0.0075$ & $38.64 \pm 4.99$ & $2095.26 \pm 85$ & $52.27 \pm 15.19$ \\
$\mathbf{1 2 4}$ & $39.6 \pm 0.11$ & $0.78 \pm 0.034$ & $0.059 \pm 0.0019$ & $50.71 \pm 2.08$ & $670.24 \pm 20.26$ & $13.22 \pm 0.14$ \\
$\mathbf{1 9 6}$ & $37.74 \pm 0.45$ & $0.53 \pm 0.044$ & $0.037 \pm 0.0011$ & $71.51 \pm 6.77$ & $1007.06 \pm 17.94$ & $14.23 \pm 1.59$ \\
$\mathbf{2 5 7}$ & $34.58 \pm 0.78$ & $0.74 \pm 0.11$ & $0.036 \pm 0.003$ & $47.35 \pm 5.79$ & $969.40 \pm 60.15$ & $20.62 \pm 1.25$ \\
$\mathbf{3 1 3}$ & $37.405 \pm 0.49$ & $0.846 \pm 0.10$ & $0.0279 \pm 0.0048$ & $44.79 \pm 4.82$ & $1378.76 \pm 220.45$ & $30.60 \pm 1.63$ \\
$\mathbf{3 7 8}$ & $37.51 \pm 0.37$ & $1.02 \pm 0.04$ & $0.035 \pm 0.02$ & $36.64 \pm 1.18$ & $1508.80 \pm 817.43$ & $40.49 \pm 21.00$ \\
\hline
\end{tabular}

The annual decomposition rates estimated here were approximately 50 and $30 \%$ for aerial and belowground tissues, respectively. The annual aerial decomposition rate for $S$. alterniflora in other salt marshes over the world varies between 45 and $90 \%$ (Table 2), which indicates that at our study site the decomposition of aboveground biomass is low but still within the range estimated for the world. The decomposition of roots and rizhomes in our study is lower than that estimated for other salt marshes elsewhere in the world, since a value of $50 \%$ has been reported in China (LIAO et al., 2008) and one of $60 \%$ on Sapelo Island (Georgia, USA) (BENNER et al., 1991), the only two studies dealing with belowground tissues. This would indicate that there is an important build up of sediment-trapped detritus in the salt marsh studied.

The low decomposition rates at our study site could be related to the chemical composition of the detritus. The ratios between elements were high in both kinds of tissues, indicating that the material was resistant to decomposition (ENRIQUEZ et al., 1993; REJMÁNKOVÁ; HOUDKOVÁ, 2006). The decomposition rate was even lower in belowground tissues, as generally observed for this species, and this is in agreement with the higher $\mathrm{C} / \mathrm{N}$ and $\mathrm{C} / \mathrm{P}$ in roots and rhizomes as compared to leaves and shoots.
Decomposition rates could also be related to physical factors, such as humidity, at the study site (WHITE; TRAPANI, 1982; ENRIQUEZ et al., 1993; REJMÁNKOVÁ; HOUDKOVÁ, 2006). Therefore, the fact that the assay was performed in the high marsh, not usually flooded by tidewater, could also contribute to the low decomposition rates. In addition, this could also explain the lack of a leaching phase, a very common stage at the beginning of the decomposition process. Leaching is the main cause of lost of weight due to the loss of soluble compounds (CÔUTEAUX et al., 1995; ANESIO et al., 2003) and perhaps a spring tide that moistens the plant material may be necessary to activate decomposition.

The concentration of nutrients in the tissues varied during the decomposition process, as has been observed in other salt marshes (e.g. KRUCZYNSKI et al., 1978; WILSON et al., 1986; TONG et al., 2011). This could be related to the activity of different groups of microorganisms at different moments (ANESIO et al., 2003) and would imply the alternate predominance of release or absorption during the process. Moreover, there were fluctuations in the $\mathrm{C} / \mathrm{N}, \mathrm{C} / \mathrm{P}$ and $\mathrm{N} / \mathrm{P}$ ratios during the process, which may reflect differences in the rate of degradation of the various elements (FLINDT et al., 1999). 
Table 2. Aproximate annual decomposition rates of aboveground tissues of $S$. alteniflora from different salt marshes over the world using the litterbag technique.

\begin{tabular}{|c|c|c|}
\hline Location & Decomposition rate & Reference \\
\hline Delacroix, Louisiana (USA) & $100 \%$ & White et al., 1978 \\
\hline Barataria, Louisiana (USA) & $90 \%$ & Kirby and Gosselink, 1976 \\
\hline Cape Cod, Massachusetts (USA) & $90 \%$ & Wilson et al., 1986 \\
\hline Beton Sound, Louisiana (USA) & $\begin{array}{c}100 \% \text { (bags put in summer) } \\
87 \% \text { (bags put in winter) }\end{array}$ & White and Trapani, 1982 \\
\hline St. Marks, Florida (USA) & $\begin{array}{l}90 \% \text { (bags in the creek) } \\
80 \% \text { (bags in the marsh) }\end{array}$ & Kruczynski et al., 1978 \\
\hline Bahía Blanca estuary (Argentina) & $80 \%$ & Montemayor et al., 2011 \\
\hline Yangtze estuary (China) & $70 \%$ & Liao et al., 2008 \\
\hline Ocean County, New Jersey (USA) & $70 \%$ & Frasco and Good, 1982 \\
\hline Rowley, Massachussetts (USA) & $70 \%$ & Montagna and Ruber, 1980 \\
\hline $\begin{array}{l}\text { Brunswick County, North Carolina } \\
\text { (USA) }\end{array}$ & $\begin{array}{l}75 \% \text { (bags in the marsh) } \\
60 \% \text { (bags in the creek) }\end{array}$ & McKee and Seneca, 1982 \\
\hline Mississippi (USA) & $52 \%$ & De la Cruz, 1973 \\
\hline Min River estuary (USA) & $45 \%$ & Tong et al., 2011 \\
\hline
\end{tabular}

In conclusion, since the decomposition rates at our study site are low, the contribution of this process to the dynamics of nutrients in the estuarine system would be long-term. Moreover, the fluctuations in the concentration of nutrients during the process should be taken into account. However, given the production of $S$. alterniflora in the Bahía Blanca estuary (GONZÁLEZ TRILLA et al., 2009) and the expansion of these salt marshes over recent years (FEDERICI et al., 2003; MAZZON et al., 2009), the role of this process in the dynamics of nutrients and organic matter in this system should not be overlooked and further research into it is desirable.

\section{REFERENCES}

ANESIO, A. M.; ABREU, P.C.; BIDDANDA, B. A. The role of free and attached microorganisms in the decomposition of estuarine macrophyte detritus. Estuar. Coast. Shelf Sci., v. 56, p. 197-201, 2003.

BENNER, R.; FOGEL, M.L.; SPRAGUE, E.K. Diagenesis of belowground biomass of Spartina alterniflora in saltmarsh sediments. Limnol. Oceanogr., v. 36, p. 1358 1374, 1991.

BIUDES, J. F. V.; CAMARGO, A. F. M. Changes in biomass, chemical composition and nutritive value of Spartina alterniflora due to organic pollution in the Itanhaém River Basin (SP, Brazil). Braz. J. Biol., v. 66, n. 3., p. 781-789, 2006.

BOCOCK, K.; GILBERT, O. The disappearance of leaf litter under different woodland conditions. Plant Soil, v. 9, p. 179-185, 1957.
BOUCHARD, V.; LEFEUVRE, J.C. Primary production and macro-detritus dynamics in a European salt marsh: carbon and nitrogen budgets. Aquat. Bot., v. 67, p. 2342, 2000.

CONTEAÛX, M-M.; BOTTNER, P.; BERG, B. Litter decomposition, climate and litter quality. Trends Ecol. Evol., v. 10, n. 2., p. 63-66, 1995.

DA CUNHA LANA, P.; GUISS, C.; DISARÓ, S.T. Seasonal variation of biomass and production dynamics for aboveand belowground components of a Spartina alterniflora marsh in the Euhaline Sector of Paranaguá Bay (SE Brazil). Estuar. Coast. Shelf Sci., v. 32, p. 231-241, 1991.

DAME, R. F. The importance of Spartina alterniflora to Atlantic coast estuaries. Crit. Rev. Aq. Sci., v. 1, p. 639660, 1989.

DE LA CRUZ, A. A. The role of tidal marshes in the productivity of coastal waters. Assoc. Southeast. Biol. Bull, v. 20, p. 147-156, 1973.

ENRIQUEZ, S.; DUARTE, C. M.; SAND-JENSEN, K. Patterns in decomposition rates among photosynthetic organisms: the importance of detritus C:N:P content. Oecologia, v. 94, p. 457-471, 1993.

FEDERICI, G.; GÓMEZ, E; CUADRADO, D.; BORGES, M. Influencia de la Spartina alterniflora en la sedimentacion en Puerto Rosales. In: V JORNADAS NACIONALES CIENCIAS DEL MAR; XIII COLOQUIO ARGENTINO DE OCEANOGRAFÍA Mar del Plata, Argentina. Proceedings... p.105, 2003.

FLINDT, M. R.; PARDAL, M. Â.; LILLEB $\emptyset$, A. I.; MARTINS, I.; MARQUES, J. C. Nutrient cycling and plant dynamics in estuaries: a brief review. Acta Oecol., v. 20 , n. 4 , p. $237-248,1999$.

FRASCO, B. A.; GOOD, R. E. Decomposition dynamics of Spartina alterniflora and Spartina patens in a NewJersey salt marsh Amer. J. Bot., v. 69, n. 3, p. 402-406, 1982. 
GONZÁLEZ TRILLA, G.; KANDUS, P.; NEGRIN, V.L.; VICARI, R.; MARCOVECCHIO, J.E. Tiller dynamic and production on a SW Atlantic Spartina alterniflora marsh. Estuar. Coast. Shelf Sci., v. 85, p. 126-133, 2009.

ISACCH, J.; COSTA, C.; RODRIGUEZ-GALLEGO, L.; CONDE, D.; ESCAPA, M.; GAGLIARDINI, D.; IRIBARNE, O. Distribution of salt marsh plant communities associated with environmental factors along a latitudinal gradient on the south-west Atlantic coast. J. Biogeogr., v. 33, n.5, p. 888-900, 2006.

JORDAN, T. E.; WHIGHAM, D.F.; CORRELL, D. L. The role of litter in nutrient cycling in a brackish tidal marsh. Ecology, v. 70, p. 1906-1915, 1989.

KIRBY, C. J.; GOSSELINK, J. G. Primary production in a Louisiana gulf coast Spartina alterniflora marsh. Ecology, v. 57, p. 1052-1059, 1976.

KRUCZYNSKI， W. L.; SUBRAHMANYAM， C. B.; DRAKE, S. H. Studies on the plant community of a North Florida salt marsh. Part II. Nutritive value and decomposition. Bull. Mar. Sci., v. 28, n. 4, p. 707-715, 1978.

LIAO, C.; LUO, Y.; JIANG, L.; ZHOU, X.; WU, X.; FANG, C.; CHEN, J.; LI, B. Invasion of Spartina alterniflora enhanced ecosystem carbon and nitrogen stocks in the Yangtze estuary, China. Ecosystems, v. 10, p. 13511361, 2007

LIAO, C.; LUO, Y.; FANG, C.; CHEN, J.; LI, B. Litter pool sizes, decomposition, and nitrogen dynamics in Spartina alterniflora-invaded and native coastal marshlands of the Yangtze estuary. Oecologia, v. 156, p. 589-600, 2008.

MARINUCCI, A.C. Trophic importance of Spartina alterniflora production and decomposition to the marshestuarine ecosystem. Biol. Conserv., v. 22, p. 35-58, 1982.

MAZZON, C.; PRATOLONGO, P.; PERILLO, G.M.E Análisis de cambios en la cobertura de las marismas del estuario de Bahía Blanca mediante el uso de matrices de transición e índices kappa. In: VII JORNADAS NACIONALES DE CIENCIAS DEL MAR; XV COLOQUIO DE OCEANOGRAFÍA. Bahía Blanca, Argentina. Proceedings...p. 335, 2009.

MCKEE, K. L.; SENECA, E. D. The influence of morphology in determining the decomposition of two salt marsh macrophytes. Estuaries v. 5, n. 4, p. 302-309, 1982.

MONTAGNA, P. A.; RUBER, E. Decomposition of Spartina alterniflora in different seasons and habitats of a Northern Massachusetts salt marsh, and a comparison with other Atlantic regions. Estuaries, v. 3, n. 1, p. 6164, 1980

MONTEMAYOR, D. I.; ADDINO, M.; FANJUL, E.; ESCAPA, M.; ALVAREZ, M. F.; BOTTO, F.; IRIBARNE, O. Effect of dominant Spartina species on salt marsh detritus production in SW Atlantic estuaries. J. Sea Res. v. 66, n. 4, p. 104-110, 2011.
MOORE, J. C.; BERLOW, E. L.; COLEMAN, D. C.; DE RUITER, P. C.; DONG, Q.; HASTINGS, A.; JOHNSON, N. C.; MCCANN, K. S.; MELVILLE, K.; MORIN, P. J.; KNUTE, N.; ROSEMOND, A. D.; POST, D. M.; SABO, J. L.; SCOW, K. M.; VANNI, M. J.; WALL, D. H. Detritus, trophic dynamics and biodiversity. Ecol. Lett., v. 7, p. 584-600, 2004.

NEGRIN, V. L.; SPETTER, C. V.; ASTEASUAIN, R. O.; PERILLO, G. M. E.; MARCOVECCHIO, J. E. Influence of flooding and vegetation on carbon, nitrogen and phosphorus dynamics in the pore water of a Spartina alterniflora salt marsh. J. Environ. Sci., v. 23, p. 212221, 2011.

PELÁEZ, M. R.; MAZZON, C.; PRATOLONGO, P. Patrones de zonación de la vegetación y distribución de la biomasa a lo largo de dos gradientes de elevacion en la zona intermareal del estuario de Bahía Blanca. In: CAZZANIGA, N. J.; ARELOVICH, H. M. (Ed.). Ambientes y recursos naturales del sudoeste bonaerense: producción, contaminación y conservación. Bahia Blanca: EdiUNS, 2009. p. 341-353.

PICCOLO, M. C.; PERILLO, G. M. E.; MELO, W. D. The Bahía Blanca estuary: an integrated overview of its geomorphology and dynamics. In: NEVES, R.; BARETTA, J.; MATEUS, M. (Ed.). Perspectives on Integrated Coastal Zone Management in South America. Part C: From shallow water to the deep fjord: the study sites. IST Press, 2008. p. 219-229

REJMÁNKOVÁ, E.; HOUDKOVÁ, K. Wetland plant decomposition under different nutrient conditions:what is more important, litter quality or site quality? Biogeochemistry, v. 80, p. 245-262, 2006.

TONG, C.; ZHANG, L.; WANG, W.; GAUCI, V.; MARRS, R.; LIU, B.; JIA, R.; ZENG, C. Contrasting nutrient stocks and litter decomposition in stands of native and invasive species in a sub-tropical estuarine marsh. Environ. Res., v. 111, p. 909-916, 2011.

WILSON, J.O.; BUCHSBAUM, R.; VALIELA, I.; SWAIN, T. Decomposition in salt marsh ecosystems: phenolic ynamics during decay of litter of Spartina alterniflora. Mar. Ecol. Prog. Ser., v. 29, p. 177-187, 1986.

WHITE, D.A.; WEISS, T.E.; TRAPANI, J.M.; THIEN, L.B. Productivity and decomposition of the dominant salt marsh plants in Louisiana. Ecology, v. 59, n. 4, p. 751759,1978

WHITE, D. A.; TRAPANI, J. M. Factors influencing disappearance of Spartina alterniflora from litterbags. Ecology, v. 63, n. 1, p. 242-245, 1982.

(Manuscript received 19 May 2011; revised 29 September 2011; accepted 03 November 2011) 